\title{
Heavy Metal Uptake and Bioaccumulation by Mangrove Grab (Goniopsis pelli) from used Drilling Mud, Niger Delta, Nigeria
}

\author{
ENYI, IO; *BABATUNDE, BB; HART, AI \\ Department of Animal and Environmental Biology, Faculty of Science, University of Port Harcourt, Nigeria \\ *Corresponding Author Email: bolaji.babatunde@uniport.edu.ng
}

\begin{abstract}
This study was carried out to evaluate some heavy metal uptake and bioaccumulation in the meat, egg and shell of $G$. pelli from used drilling mud. The experimental approach involved the exposure of ten of the test organism G. pelli to six acute concentrations of drilling mud representing $0 \%$ (control), $10 \%, 20 \%, 30 \%, 40 \%$ and $50 \%$ for 96 hours in three replicates after the range finding test was conducted to determine the $\mathrm{LC}_{50}$. From the $\mathrm{LC}_{50}$, the test organism was further exposed to four sub-lethal concentrations of drilling mud $(0 \%, 5 \%, 10 \%$ and $15 \%)$ for 21 days to evaluate the heavy metal uptake by the test organism. the result showed that heavy metal uptake increased in the order of meat $(<0.001-2.36 \pm 0.12)$, shell $(<0.001-3.31 \pm 0.19)$ and $\operatorname{egg}(<0.001-0.54 \pm 0.05)$ when compared with those in control tank. Copper was highest $(3.31 \mu \mathrm{g} / \mathrm{g})$ in the shell and lowest $(0.26 \mu \mathrm{g} / \mathrm{g})$ in the egg; zinc was highest $(2.36 \mu \mathrm{g} / \mathrm{g})$ in the meat and lowest $(0.22 \mu \mathrm{g} / \mathrm{g})$ in the shell; chromium was highest $(0.12 \mu \mathrm{g} / \mathrm{g})$ in the meat and lowest $(0.06 \mu \mathrm{g} / \mathrm{g})$ in the egg; cadmium was highest $(0.2 \mu \mathrm{g} / \mathrm{g})$ in the shell and lowest $(0.001 \mu \mathrm{g} / \mathrm{g})$ in the egg while lead had equal value $(<0.001)$ in the meat, shell and egg of the test organism. This could pose a very serious health challenge to the consumers of G. pelli and other aquatic fishery resources if nothing is done to ensure the best practice in drilling activities in other to avoid pollution of the water bodies through drilling.
\end{abstract}

DOI: https://dx.doi.org/10.4314/jasem.v24i3.13

Copyright: Copyright $\left(C^{\circ} 2020\right.$ Enyi et al. This is an open access article distributed under the Creative Commons Attribution License (CCL), which permits unrestricted use, distribution, and reproduction in any medium, provided the original work is properly cited.

Dates: Received: 16 November 2019; Revised: 11 January 2020; Accepted: 22 February 2020

Keywords: Heavy metals, bioaccumulation, drilling mud, Goniopsis pelli

Heavy metals constitute a very heterogenous group of elements widely varied in their chemical properties and biological functions. They are kept under environmental pollutant category due to their toxic effects on plants, animals and human being. Bioaccumulation of heavy metals in living organisms defines the processes and path- ways of pollutants from one trophic level to another. Heavy metals concentrations in the aquatic organism depict the past as well as the current pollution load in the environment in which the organism lives (Ravera et al, 2003.). Pollution of the aquatic environment by inorganic chemicals has been considered a major threat to the aquatic organisms including fishes. Niger Delta is one of the world's most severely petroleum impacted ecosystems' undergoing damage from oil operations which is acute, chronic and cumulative. This has acted synergistically with other sources of environmental stress to result in a severely impaired coastal ecosystem and compromised the livelihoods and health of the inhabitants of the delta who rely on fisheries, subsistence agriculture and associated processing industries for their livelihood. Crabs are of economic importance to the people of Niger Delta. They are rich in protein and are used daily for food. Their nutritional value compares favourably with those of domestic livestock and fish (Horsfall et al., 2008). The objective of this study therefore, is to determine the lethal and sub-lethal effects of oil based drilling mud using the integration of bioaccumulation of heavy metals and oxidative stress analysis as measurement of stress indices to determine the susceptibility of this mangrove crab (G. pelli) in the environment.

\section{MATERIALS AND METHOD}

Study area: The samples were collected in Sivibilagbara, a protected mangrove swamp, and on four isolated, open, unvegetated intertidal flats along the Dor Nwezor channel of Bodo Creek (435'26.3"$4^{\circ} 36^{\prime} 29.7^{\prime \prime} \mathrm{N}, 7^{\circ} 15^{\prime} 30.2^{\prime \prime}-7^{\circ} 16^{\prime} 50.9^{\prime \prime}$ E) Figure 1 Sikoki and Zabbey (2006).

The samples were collected at different sampling stations, chosen to cover the various biotopes available on isolated intertidal flats fringing the Dor Nwezor main channel. The crabs were collected at low tide and transported to the Hydrobiology \& Fisheries laboratory, Department of Animal and Environmental Biology, Faculty of Science, University of Port Harcourt in a plastic bucket perforated to allow air. 


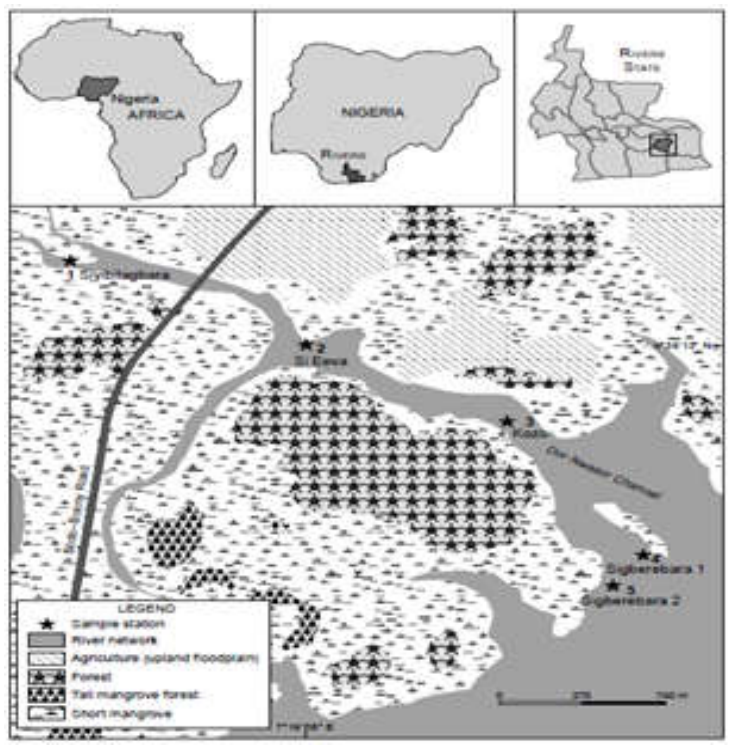

Fig.1: Map of Dor Nwezor Channel, Bodo Creek, Nigeria, indicating locations of sample sites Collection and Acclimatization

In the laboratory, the test organisms were immediately transferred to the holding tanks after length and weight measurements had been taken. They were conditioned for one week in the laboratory and left to acclimatize in eighteen plastic bowls of 30 litre capacity. This was to ensure that the test organisms will survive in the conditioned environment without showing signs of stress, damage or wounds from discolouration or unusual behaviour (Reish and Oshida, 1986).

Experimental Set-up: The test organisms were exposed to six different concentration tanks and the experiment conducted in three replicates for each concentration. In all 18 tanks were used for the species for the acute toxicity experiment.

Length and Weight Measurement: The length measurement of the crabs was determined using a meter rule on a measuring board in centimeters $(\mathrm{cm} 3)$. An HX-Z electronic balance was used to measure the weight in grammes $(\mathrm{g})$. Water was dabbed off crabs with filter paper before weighing Table 1.

Table 1: Size selection of the test organisms

\begin{tabular}{|l|l|l|}
\hline Organism & Mean body length range & Mean weight range \\
\hline Goniopsis pelii & $13.5 \mathrm{~cm}$ & $29.83 \mathrm{~g}$ \\
\hline
\end{tabular}

Preparation of Test Material for Acute Toxicity: The drilling mud obtained from Agip terminal brass used for the acute toxicity was prepared at the laboratory in advance and added immediately to the dilution water for the bioassay to obtain the different treatment concentrations. $100 \mathrm{~g} / \mathrm{l}$ in tank one, $200 \mathrm{~g} / 1,300 \mathrm{~g} / \mathrm{l}$, $400 \mathrm{~g} / \mathrm{l}$ and $500 \mathrm{~g} / \mathrm{l}$ in the various tanks and this was mixed using a mixer for about 30 minutes to ensure homogeneity. This mixture was allowed to settle for one hour prior to the introduction of the test organisms (Reish and Oshida, 1986). The toxicant "drilling mud" was prepared using volumetric displacement in a 1 litre ratio of 1:9 (Finery, 1971). The following concentrations were obtained and used for the experiment $0 \%$ (control), $10 \%, 20 \%, 30 \%, 40 \%$ and $50 \%$ for the Goniopsis pelii(i.e. $10 \% \mathrm{OBM}=10 \mathrm{ml} / \mathrm{L}$ ) and a $1 \mathrm{~kg}$ mud from where the test organisms were collected was added to each of the tanks.

Preparation of Bioassay Media for Acute Toxicity: A completely randomized design was carried out (Ogbeibu, 2005) in which healthy organisms after acclimatization were selected and placed in appropriate 50 litre tanks at 10 specimens per tank and covered with a net to allow for air and prevent the crabs from escaping.

Bioassay for Acute Toxicity: Goniopsis pelii (Mangrove crab) were exposed to OBM solution for 96hours following the methods of Sprague (1970) and FAO (1973). Eighteen (18) plastic containers (30 litres) were used with six treatment concentrations of $0 \%$ (control), $10 \%, 20 \%, 30 \%, 40 \%$, and $50 \%$. The test was conducted under room temperature using static non-renewal bioassay (EPA, 2000). The exposure lasted for 96 hours (4 days) within which mortalities, general conditions and behaviours exhibited by the test organisms were observed and recorded at the following periods 15 minutes, 1 hour, 4 hours, 8 hours, then 12 hourly until the end of the experiment.

Determination of Heavy Metals in the Test Organism: Analysis of heavy metal content in the drilling mud used, meat of the exposed and unexposed organism, shell of the exposed and unexposed organism, eggs of the exposed and unexposed organisms, were carried out for chromium $(\mathrm{Cr})$, cadmium $(\mathrm{Cd})$, lead $(\mathrm{Pb})$, copper $(\mathrm{Cu})$ and zinc $(\mathrm{Zn})$ at their various levels of metals present after exposure for 21 days. The well labeled samples were arranged in the oven and the charcoal heated. The heated charcoal was placed in the charcoal chamber of the local oven to dry the sample at a temperature between $760 \mathrm{C}-85 \mathrm{oC}$. The sample was placed in mortar after cleaning the mortar with hydrogen peroxide using cotton wool to avoid cross contamination of each sample and ground with the pestle to a powdered form. $10 \mathrm{ml}$ of hydrogen peroxide was measured using measuring cylinder and poured into a beaker containing $3 \mathrm{~g}$ of the sample and boiled for 2-3 minutes to hasten the digestion. It was allowed to cool. Then $10 \mathrm{ml}$ of hydrochloric acid and $30 \mathrm{ml}$ of nitric acid were added and mixed homogenously. The beaker was placed on the heat source and allowed to 
heat until it got digested at a temperature of $650 \mathrm{C}$ $70 \circ \mathrm{C}$

\section{RESULTS AND DISCUSSION}

Physicochemical Parameters: The summarized data on the physicochemical parameters showing the mean values and the standard error obtained are presented in Fig.2. The temperature values had a narrow range throughout the study with the minimum mean temperature of $26.730 \mathrm{C}$ recorded at treatment exposed to $40 \% \mathrm{OBM}$ and the maximum mean temperature of $29.630 \mathrm{C}$ recorded for treatment at $0 \%$ (control). There was significant difference $\mathrm{p} \geq 0.05$ in temperature for the concentration used and the species exposed. A narrow range was obtained for $\mathrm{pH}$ with mean values that ranged from 6.33-6.83 with significant difference of $\mathrm{p} \geq 0.05$ between the concentrations. Dissolved oxygen (DO) values obtained ranged from $4.20 \mathrm{mg} / 1$ $5.80 \mathrm{mg} / \mathrm{l}$. It tended to vary slightly from one concentration to another with decrease from the lowest concentration to the highest concentration. However, there was no significant difference in the various concentrations. Total Dissolved Solid (TDS) values tend to vary slightly from 14.20 to 15.60 as the concentration increased from $0 \%-50 \%$. There was no significant difference that existed between the various concentrations. Similarly, the value for conductivity decreased from 19.57 to 17.56 with increased concentrations. The results from the study showed that the water quality fell within the range recommended and the variations that occurred among the parameters measured were within the tolerable ranges throughout the bioassay tests (Bolarin and Halton, 2009). The dissolved oxygen of $4.2 \mathrm{mg} / 1$ and $5.8 \mathrm{mg} / \mathrm{l}$ obtained in the study was normal compared to stipulated limits and is conducive for the survival of the test organism (Goniopsis pelii) under non-renewable static bioassay. This result agrees with the work of Okogbue (2014) who reported that dissolved oxygen ranged from $3.45 \mathrm{mg} / 1$ to $5.95 \mathrm{ml} / 1$ for $M$. macrobrachion exposed to N.P.K. fertilizer as toxicant was conducive for the survival of the test organism. Similarly, the temperature range of $260 \mathrm{C}$ to $29 \mathrm{oC}$ fell within the acceptable limit (EIFAC, 2003). This result agrees with the results reported by Gbadebo et al., (2010) and Hartley et al., (2003). The pH values of $6.3-6.8$ obtained from this study conforms to the recommended range of $6-9$ for the survival of tropical fishes. The high salinity range of $15.0-15.3$ obtained from the study could be attributed to the saline nature of brackish waters. The values for total dissolved solid (TDS) was found to be lowest (14.20) in the control tank and highest (15.60) in 40\% concentration tank. The increase in TDS values could be attributed to increase in the concentration of the toxicant and this result agrees with the result of other authors (Okogbue; 2014, Nwakanma, 2012). Similarly, the values for conductivity varied slightly as the concentration increased. The variations in the water quality observed did not adversely alter the water quality integrity and were in conformity with the finding of different authors (Wade et al., 2002; Omoregie et al., 1990; Annue and Ajike, 1999; Aguigwo, 2002; Okoli-Annuobi et al., 2002).

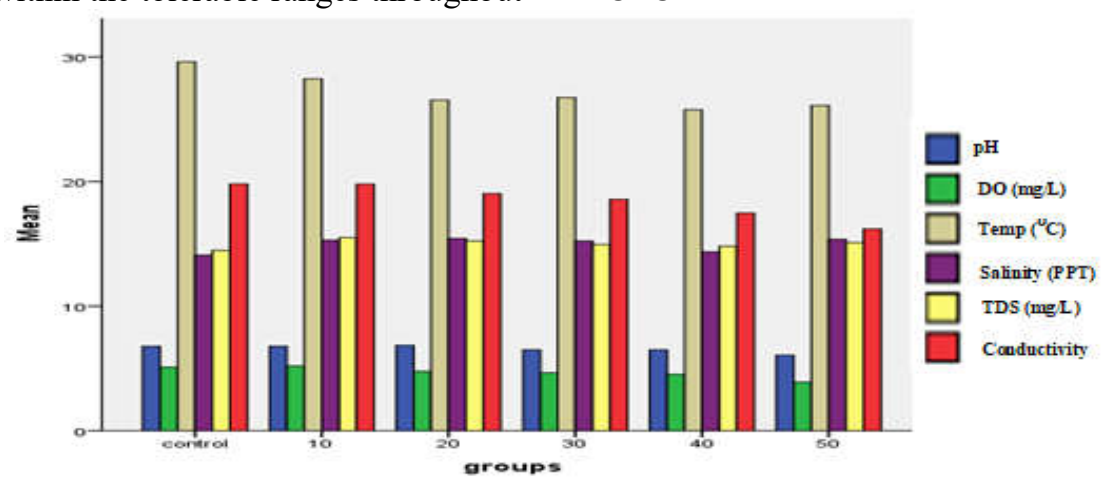

Fig.2: Mean values of physicochemical parameters of the test media against the concentrations

Mortality: The effect of the different concentrations of OBM on Goniopsis pelii showed marked variations during the course of the experiment. No mortality was recorded in the control test media Table 2. However, mortality increased with increase in drilling mud concentrations over time. After 24hours, only one specimen died in the $100 \mathrm{~g} / \mathrm{l}$ and $200 \mathrm{~g} / 1$ concentration respectively; while mortality increased to 4 in $300 \mathrm{~g} / 1$, 8 in $400 \mathrm{~g} / 1$ and 13 in $500 \mathrm{~g} / 1$ concentrations respectively. However, after 96hours of exposure, a total of 3 representing $9.99 \%$ died in the $100 \mathrm{~g} / 1$ concentration, 15 in $200 \mathrm{~g} / 1,17$ in $300 \mathrm{~g} / 1,25$ in $400 \mathrm{~g} / 1$ and 30 in $500 \mathrm{~g} / 1$ representing $49.99 \%, 56.65 \%$, $83.31 \%$ and $99.99 \%$ mortality Table 2 . The result of the analysis showed that as the concentration increased, more death were recorded and as the time increased, the $\mathrm{LC}_{50}(200 \mathrm{~g} / 1$ conc.) reduced. Generally, mortality is indicative of the end point for toxicity test (Odiete, 2009). Therefore, the main biological parameter monitored in this study among others is 
mortality. From the study, mortality increased with increase in concentration of drilling mud over time of exposure which was in agreement with previous findings by other authors (OGP, 2003, Bowmer et al., 1996 ) at 24 hours, mortalities of $0 \%$ was recorded for the control tank, $3.33 \%$ for $100 \mathrm{~g} / 1,3.33 \%$ for $200 \mathrm{~g} / \mathrm{l}$, $13.33 \%$ for $300 \mathrm{~g} / 1,26.66 \%$ for $400 \mathrm{~g} / \mathrm{l}$ and $43.33 \%$ for $500 \mathrm{~g} / \mathrm{l}$ concentrations respectively. However the mortality increased with time and was found to have risen to $9.99 \%$ in $100 \mathrm{~g} / 1,49.99 \%$ in $200 \mathrm{~g} / 1,56.65 \%$ $300 \mathrm{~g} / \mathrm{l}, 83.31 \%$ in $400 \mathrm{~g} / \mathrm{l}$ and $99.99 \%$ in $500 \mathrm{~g} / \mathrm{l}$ concentrations respectively after 96 hours of exposure. However, Nwakanma (2012) reported mortalities of $0 \%, 3 \%, 10 \%, 13 \%$ and $20 \%$ after 24 hours of exposure to $P$. papilio to toxicant and $30 \%, 40 \%, 50 \%, 57 \%$ and
$73 \%$ at 96 hours. Although the values varied slightly from the result of this study but the result shows that there is an increase in mortality as the concentration increases with time. Similarly, Nte (2014), VincentAkpu (2006), Nafagha (2014) and Okogbue (2014) also noted that the mortality rate increased with increase in concentration as the time increased in their various reports. The absence of mortality in the control tank shows that mortality was caused by the drilling mud. This confirms that drilling muds are toxic to the test organism (Goniopsis pelii). Neff et al., (1981) also noted that if mud aqueous fraction was renewed daily, its toxicity will decrease seven fold, demonstrating that the toxic component may be lost from solution by volatilization.

Table 2: Mortality (mean numbers and percentage) of Goniopsis pelii exposed to OBM for 96 hours

\begin{tabular}{|c|c|c|c|c|c|c|c|c|c|c|}
\hline Time & & & 24 hours & & 48 hours & & 72 hours & & 96 hours & \\
\hline $\begin{array}{l}\text { Conc. } \\
(\%)\end{array}$ & $\begin{array}{l}\text { No. of } \\
\text { organism }\end{array}$ & Rep & Mortality & $\begin{array}{l}\text { \% } \\
\text { mortality }\end{array}$ & Mortality & $\begin{array}{l}\% \\
\text { mortality }\end{array}$ & Mortality & $\begin{array}{l}\% \\
\text { mortality }\end{array}$ & Mortality & $\begin{array}{l}\% \\
\text { mortality }\end{array}$ \\
\hline Control & 10 & 3 & - & - & - & - & - & - & - & - \\
\hline 10 & 10 & 3 & 1 & 3.33 & 1 & 3.33 & 1 & 3.33 & 0 & 0 \\
\hline 20 & 10 & 3 & 1 & 3.33 & 2 & 6.66 & 6 & 20 & 6 & 20 \\
\hline 30 & 10 & 3 & 4 & 13.33 & 2 & 6.66 & 7 & 23.33 & 4 & 13.33 \\
\hline 40 & 10 & 3 & 8 & 26.66 & 5 & 16.66 & 11 & 36.66 & 1 & 3.33 \\
\hline 50 & 10 & 3 & 13 & 43.33 & 7 & 23.33 & 7 & 23.33 & 3 & 10 \\
\hline
\end{tabular}

Uptake of Heavy Metal: The results of the uptake of heavy metals in the shell, meat and egg of the test organism exposed to toxicant and those unexposed to toxicant are presented in the Figures 3-6.

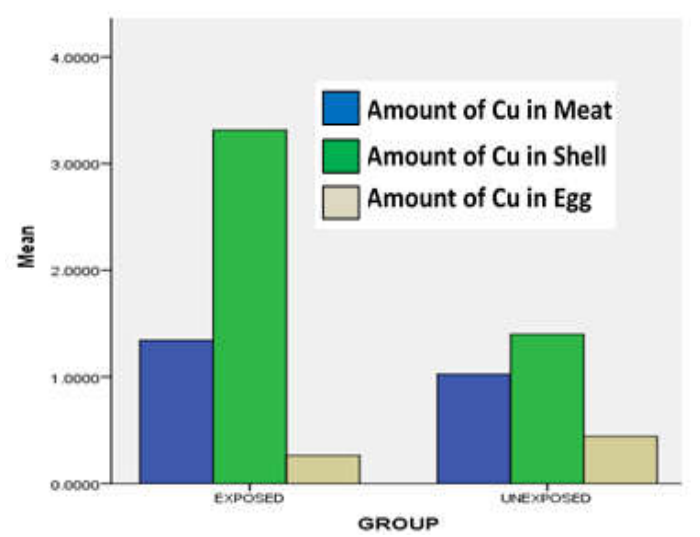

Fig 3: Relationship between the copper concentration in the meat, shell and egg of test organisms exposed to drilling mud and those unexposed after 21 days of sub-lethal bioassay.

The values for each metal were as follows: Copper $1.013 \mu \mathrm{g} / \mathrm{g}, 3.32 \mu \mathrm{g} / \mathrm{g}$ and $0.2 / \mathrm{g}$ in meat, shell and egg respectively of the test organism exposed to drilling fluid and $1.025 \mu \mathrm{g} / \mathrm{g}, 1.4 \mu \mathrm{g} / \mathrm{g}$ and $0.447 \mu \mathrm{g} / \mathrm{g}$ in the control organism respectively Fig. 3.

Chromium $0.12 \mu \mathrm{g} / \mathrm{g}, 0.098 \mu \mathrm{g} / \mathrm{g}$ and $0.067 \mu \mathrm{g} / \mathrm{g}$ in the meat, shell and egg of the test organism exposed to drilling fluid respectively and $0.105 \mu \mathrm{g} / \mathrm{g}, 0.083 \mu \mathrm{g} / \mathrm{g}$ and $0.0218 \mu \mathrm{g} / \mathrm{g}$ for the meat, shell and egg of those not exposed to drilling fluid Fig. 4.

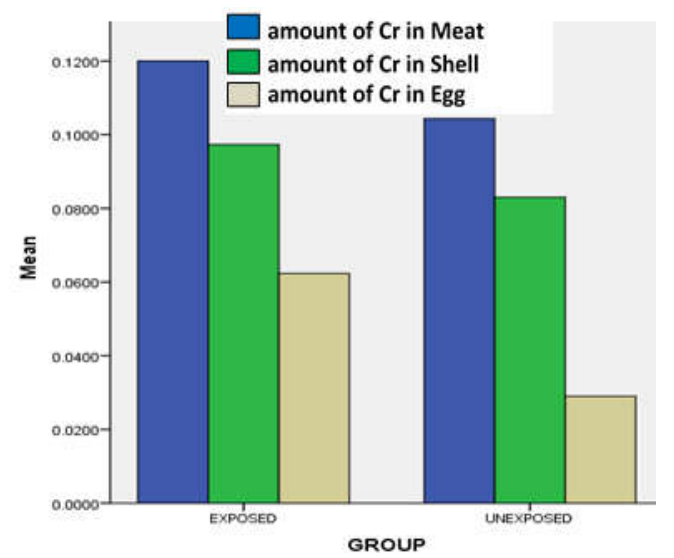

Fig.4: Relationship between the chromium concentration in the meat, shell and egg of test organisms exposed to drilling mud and those unexposed after 21 days of sub-lethal bioassay

For cadmium it was $0.002 \mu \mathrm{g} / \mathrm{g}, \quad 0.021 \mu \mathrm{g} / \mathrm{g}$, and $<0.001 \mu \mathrm{g} / \mathrm{g}$ for meat, shell and egg of test organism exposed to drilling mud and $<0.001 \mu \mathrm{g} / \mathrm{g}$, $<0.001 \mu \mathrm{g} / \mathrm{g}$ and $0.003 \mu \mathrm{g} / \mathrm{g}$ for the meat, shell and egg of the test organism not exposed to toxicant respectively Fig. 5. For zinc it was $1.213 \mu \mathrm{g} / \mathrm{g}$, $0.211 \mu \mathrm{g} / \mathrm{g}$, and $0.51 \mu \mathrm{g} / \mathrm{g}$ for meat, shell and egg of test organisms exposed to the toxicant and $0.99 \mu \mathrm{g} / \mathrm{g}$, $0.55 \mu \mathrm{g} / \mathrm{g}$ and $0.912 \mu \mathrm{g} / \mathrm{g}$ for the meat, shell and egg of the test organism in the control Fig. 6. 


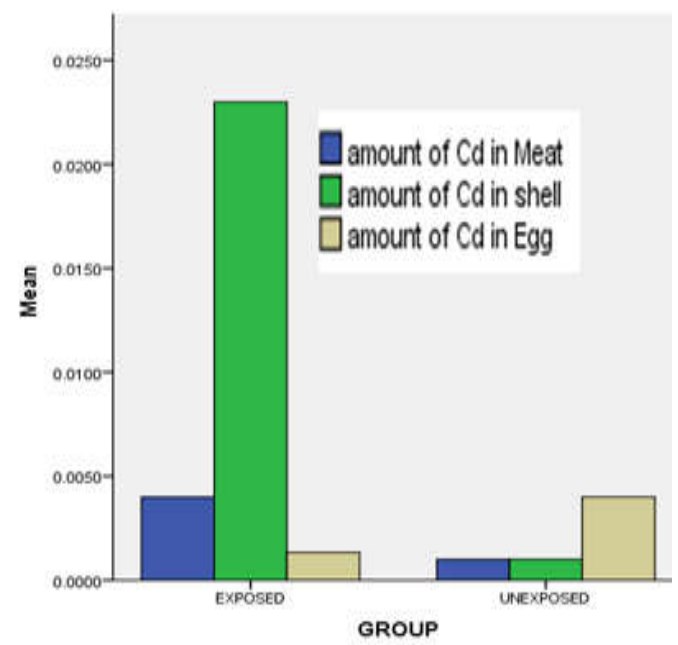

Fig. 5: Relationship between the Cadmium concentration in the meat, shell and egg of test organisms exposed to drilling mud and those unexposed after 21 days of sub-lethal bioassay

Lead was found to have the same value of $<0.001 \mu \mathrm{g} / \mathrm{g}$ in meat, shell and egg of the test organism exposed and unexposed to toxicant.In summary, Copper $(\mathrm{Cu})$ was found to be highest in the shell of the test organism exposed to drilling mud, zinc was highest in the meat and egg while lead was found to be lowest in all. Statistical analysis showed no significant difference in lead $(\mathrm{Pb})$ Chromium $(\mathrm{Cr})$ and Cadmium $(\mathrm{Cd})$ for test organisms exposed to the toxicant Fig. 7.

Crabs may be affected directly by the uptake of oil through water contaminated sediments and food materials. It was observed in this study that the uptake of heavy metals increased in the test organism exposed to drilling mud as compared to those that were not exposed with the highest uptake of copper in the shell which is directly in contact with the drilling mud and zinc in the meat which is edible. The results from this study however agrees with the finding of several authors that drilling mud additives contain toxic substances such as heavy metals, hydrocarbons sodium, biocide and organic polymers (James et al., 2000; Odiete, 1999; Jeffery and Kaplan, 1989; Morton, 1987; Nwakanma, 2012).

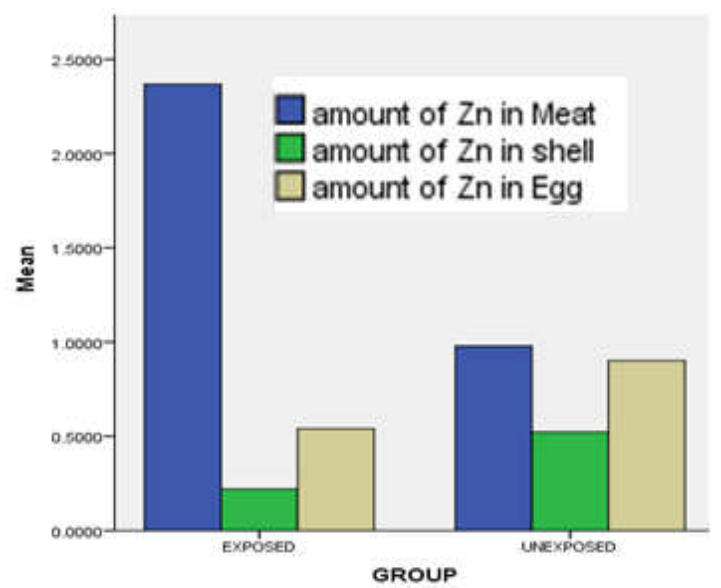

Fig. 6: Relationship between the zinc concentration in the meat, shell and egg of test organisms exposed to drilling mud and those unexposed after 21 days of sub-lethal bioassay

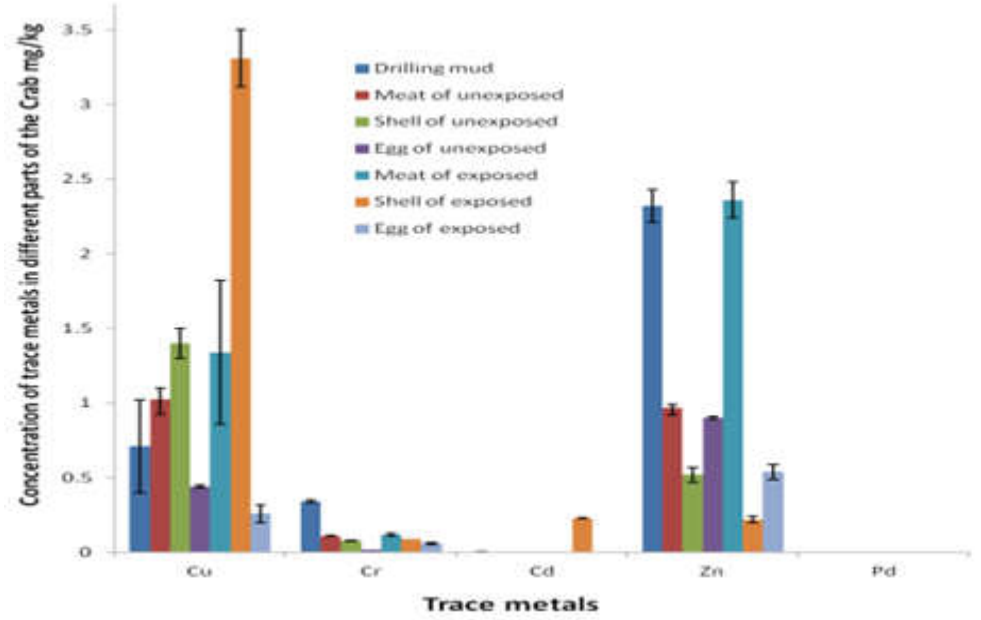

Fig. 7: Summary of heavy metal uptake in the meat, egg and shell of the test organism exposed to toxicant and those not exposed

Copper had the highest concentration in the shell of the test organism followed by the meat and then the egg in both the exposed and unexposed. This may be as a result of the direct contact of the shell to the toxicant for a longer period of time than the other parts. The intake of chromium was found to be highest in the meat of the exposed when compared with the unexposed. Cadmium was found to be highest in the shell of the exposed when compared with the meat and the egg. Zinc intake was found to be highest in the meat of the exposed when compared with the shell and 
the egg. Lead had same value for all compartments in both the exposed to drilling mud and unexposed.

Conclusion: From the results obtained in this study, it has been established that drilling mud has toxic effect on crabs which can destroy their role in the ecosystem thereby causing congestion in the ecosystem. There could be a multiple effect on human health when these contaminated crabs are consumed. Therefore, this study has added to scientific knowledge by providing information on the consequences of the toxic effect of used drilling mud on a G.pelli and potentially on human health since the tested heavy metals could bioaccumulate in the edible tissues of the crab.

\section{REFERENCE}

Aguigwo, JN (2002). The toxic effect of cymbush pesticide on growth and survival of African catfish, clarias gariepinus (Nurchell). Journal of Aquatic Sciences. 6:13-17.

Annue, PA; Ajike, SU (1999). Acute toxicity and gill morphology of $O$. niloticus (Trewavas) exposed to Rogo. Journal of Aquatic Sciences 14:1-4

Bowmer, CT; Gimeno, S; Foekema, EM; Kaag, NHBM (1996). An environmental evaluation of cleaned drill cutting using a long-term model ecosystem bioassay. In: The Physical and Biological Effects of Processed oily drill cuttings. London: E. \& P Forum Joint Study. Pp. 64-78

EIFAC (2003). European Inland Fisheries Advisory Commission Revised Report on fish toxicity testing procedure. EIFAC Technical paper 24. Revision 1. p37

EPA (2000). Development Document for final effluent limitations. Guidelines and standards for syntheticbased drilling fluids and other non-aqueous drilling fluids in the oil and gas extraction point source category. US EPA office of water. Washington D.C. EPA 821-B-00-013.

Gbadebo, AM; Taiwo, MA; Eughele, U (2010). Environmental aspect of oil and water-based drilling muds and cuttings from Dibi and Ewan off-shore wells in the Niger Delta, Nigeria. African Journal of Environmental Science and Technology, 4(5):284292

Hartley, JR; Trueman, S; Anderson, J; Neff, KF; Dando, P (2003). Drill cuttings initiative: Food Chain effects literature review. United Kingdom offshore operations Association, Aberdeen, Scotland. $118+$ Appendices
Horsfall, M; Ogban, FE; Spiff, AI (2008) petroleum hydrocarbon pollution: the distribution in sediment and water of the New Calabar River, Port Harcourt, Nigeria. The Science of the Total Environment. 141:217-221.

Nafagha, MO; (2014). The effects of water soluble fractions of crude oil on edible frogs (Ptychadena mascariensis) in the Niger Delta, Nigeria. A P.hd thesis submitted to college of graduate studies, University of Port Harcourt.

Neff, JM; Carr, RS; McCulloc, WL (1981). Acute toxicity of a used chrome lignosulphonate drilling mud to several species of marine invertebrate. Marine Environmental Resource. 4: 251-266.

Nte, ME (2014) Physiological responses of mudskipper (Periophthalmus papilio) to the biocide, sodium bromide. A P.hd thesis submitted to college of graduate studies, University of Port Harcourt.

Nwakanma, C (2012). A study of the effects of oil-based muds on the fingerlings of two species of Niger Delta mudskipper Periophthalmusbarbarous (Linneaus, 1766) and periophthalmus papilio (Boch and Schnider, 1801) A P.hd thesis submitted to college of graduate studies, University of Port Harcourt, Nigeria.

OGP, (2003). Environmental aspects of the use and disposal of non-aqueous drilling fluids associated with offshore oil and gas operations. Report No. 342 . pp. 103.

Omoregie, E; Ufodike, EBC; Keke, IR. (2009). Tissue Chemistry of $O$. niloticus exposure to sub-lethal concentrations of gammalin 20 and Actellic 25EC. Journal of Aquatic Sciences 5.33-36.

Ravera, RC; Beone, GM; Dantas, M; Lodigiani, P. (2003) "Trace Element Concentrations in Freshwater Mussels and Macrophytes as Related to Those in Their Environ- ment," Journal of Limnology, 62 (1): 61-70.

Sikoki, FD. and Zabbey, N. (2006). Aspects of Fisheries of the middle reaches of Imo River, Niger Delta, Nigeria. Environment and Ecology 24(2):309 - 312.

Vincent-Akpu, IF. (2006) The toxicity of two drilling fluids XP-07 and parateq on three life stages of Tilapia guineensis (Blecker 1862) in the Niger Delta wetlands, Nigeria. A P.hd thesis submitted to college of graduate studies, University of Port Harcourt. 